\title{
Transfer Teknologi Okulasi Durian di Kelompok Tani Harapan Baru I Kelurahan Batu Putuk Bandar Lampung
}

\section{Transfer Technology of Grafting Durian In Farmer Group Harapan Baru I Kelurahan Batu Putuk Bandar Lampung}

\author{
Rizka Novi Sesanti, Hilman Hidayat, dan Nurman Abdul Hakim \\ Jurusan Budidaya Tanaman Pangan Politeknik Negeri Lampung \\ Jln. Soekarno-Hatta No 10, Rajabasa, Bandar Lampung . \\ Tlp (0721) 703995, Fak. (0721) 787309, Hp: 08197953905 , \\ e-mail: rizkanovisesanti@yahoo.com
}

\begin{abstract}
Technology transfer about durian grafting in Harapan Baru I farmers Group, Batu Putuk village, Bandar Lampung city has been done. This activity aims to improve ( 1 ) knowledge of members of Harapan Baru I Farmers Group about characteristics durian superior. ( 2 ) knowledge of members of Harapan Baru I Farmers Group in durian grafting techniques . ( 3 ) skills of members of Harapan Baru I Farmers Group in durian grafting techniques. The method used is counseling, demonstration and practice . Evaluation used is initial evaluation , final evaluation, and evaluation success durian grafting. Results of activity showed that ( 1 ) knowledge of members of Harapan Baru I Farmers Group in characteristics durian superior reached $87.06 \%$. (2) knowledge of members of Harapan Baru I Farmers Group in durian grafting technique reached $87.06 \%$.

(3) Skills of members of Harapan Baru I Farmers Group in durian grafting techniques increased from $10 \%$ to $60 \%$.
\end{abstract}

Key words : durian, Batu Putuk, grafting

Diterima: 19-02-2014, disetujui: 02-05-2014

\section{PENDAHULUAN}

Kelompok Tani Harapan Baru I merupakan salah satu organisasi yang mewadahi petani di Kelurahan Batu Putuk. Kelompok Tani ini sedang dipersiapkan menjadi kelompok penangkar bibit buah untuk wilayah Kota Bandar Lampung oleh Dinas Pertanian Kota Bandar Lampung. Kelompok tani Harapan Baru I diketuai oleh Bapak Nani Ubai, umur 59 tahun. Jumlah anggota kelompok tani Harapan Baru I sebanyak 90 orang, dengan wilayah perkebunan mencapai 35 ha. Kebun milik anggota Kelompok Tani Harapan Baru I berisi aneka macam komoditas seperti durian, pisang, manggis, duku, petai, jengkol, kakao, pinang, dan sebagainya. Namun yang paling mendominasi adalah komoditas durian (Kelompok Tani Harapan Baru I, 2013). 
Saat ini Kelompok Tani Harapan Baru I sedang melakukan kegiatan perbanyakan tanaman durian lokal Kelurahan Batu Putuk. Salah satu varietas durian yang diperbanyak adalah Durian Putar Alam. Durian Putar Alam merupakan durian Unggul Nasional yang berasal dari Kelurahan Batu Putuk dan telah dilepas oleh Departemen Pertanian (Santoso, Haryanti, Pinem, dan Maryadi, 2008).

Perbanyakan tanaman durian yang biasa dilakukan kelompok tani Harapan Baru I adalah okulasi. Okulasi merupakan teknik perbanyakan tanaman dengan menempelkan mata tunas dari tanaman yang memiliki sifat unggul pada batang bawah sehingga menjadi satu kesatuan yang utuh dan tumbuh menjadi satu tanaman setelah terjadi regenerasi pada bekas tempelan (Prastowo, Roshetko, Maurung, Nugraha, Tukan, dan Harum, 2006).

Permasalahan yang dihadapi Kelompok Tani Harapan Baru I dalam kegiatan perbanyakan tanaman melalui teknik okulasi adalah rendahnya persen keberhasilan okulasi. Hal ini diduga disebabkan kurangnya pengetahuan dan keterampilan petani mengenai teknik okulasi yang benar. Berdasarkan hasil wawancara dengan Kelompok Tani Harapan Baru I, dari 300 bibit durian yang diokulasi hanya 27 bibit yang berhasil. Artinya tingkat keberhasilan okulasi yang dilakukan Kelompok Tani Harapan Baru I masih sangat rendah yaitu berkisar 10\%. Oleh karena itu perlu dilakukan kegiatan transfer teknologi okulasi durian melalui penyuluhan dan demonstrasi untuk meningkatkan persen okulasi jadi di Kelompok Tani Harapan Baru I.

Tujuan dari kegiatan transfer teknologi okulasi durian di Kelompok Tani Harapan Baru I Kelurahan Batu Putuk Bandar Lampung adalah : 1) Meningkatkan pengetahuan anggota Kelompok Tani Harapan Baru I mengenai ciri-ciri durian unggul/berkualitas; 2) Meningkatkan pengetahuan anggota Kelompok Tani Harapan Baru I mengenai perbanyakan tanaman durian dengan teknik okulasi; 3) Meningkatkan keterampilan petani dalam perbanyakan tanaman durian dengan teknik okulasi sehingga persentase keberhasilan bibit yang diokulasi dari $10 \%$ menjadi $60 \%$.

\section{METODE}

Kegiatan transfer teknologi okulasi durian dilaksanakan di Kelompok Tani Harapan Baru I, Kelurahan Batu Putuk, Kecamatan Teluk Betung Utara, Kota Bandar Lampung Waktu pelaksanaan dari bulan Juni sampai September 2013. Khalayak sasaran dalam kegiatan ini adalah anggota Kelompok Tani Harapan Baru I yang dipilih oleh ketua kelompok dengan pertimbangan adalah anggota kelompok yang aktif, dan memiliki tanggung jawab yang tinggi terhadap kelompok berjumlah 17 orang. Metode pelaksanaan yang digunakan dalam kegiatan ini adalah

\section{Penyuluhan dan diskusi}

Materi yang disampaikan dalam kegiatan penyuluhan dan diskusi adalah ciri-ciri durian unggul dan teknik okulasi durian dengan model forkert dan segi empat. Tahap ini bertujuan untuk meningkatkan tingkat pengetahuan (kognitif) petani mengenai ciri durian unggul dan teknik okulasi yang benar.

\section{Demonstrasi}

Pada tahap ini perserta diberikan demonstrasi mengokulasi tanaman durian oleh Tim Penyuluh.Peserta diharapkan lebih mengerti teknik okulasi yang benar dan mampu merubah sikap (afektif) untuk menerapkan materi yang telah disampaikan pada saat penyuluhan dan diskusi. 
Rizka Novi Sesanti, Hilman Hidayat, dan Nurman Abdul Hakim: Transfer Teknologi Okulasi Durian ...

\section{Praktik}

Setelah melaksanakan tahap penyuluhan dan demonstrasi maka tahapan terakhir yang dilaksanakan adalah tahap penerapan. Pada tahap ini peserta melakukan praktik okulasi tanaman durian yang sudah dipelajari melalui kegiatan penyuluhan dan demonstrasi. Metode yang dilakukan adalah 17 peserta akan diberikan masing-masing 2 batang bawah durian kemudian akan diokulasi dengan model okulasi segi empat dan model okulasi forkert.

Monitoring hasil okulasi akan dilakukan 1 bulan kemudian dengan melihat hasil okulasi tanaman durian yang berhasil. Banyaknya hasil okulasi yang berhasil akan dibandingkan dengan jumlah total durian yang diokulasi.

Evaluasi kegiatan akan dilakukan dalam tiga bentuk, yaitu evaluasi pertama, evaluasi kedua, dan evaluasi ketiga.

1. Evaluasi pertama dilakukan sebelum pelaksanaan kegiatan penyuluhan dan demonstrasi dengan memberikan kuisioner mengenai ciri-ciri durian unggul dan teknik okulasi durian. Evaluasi ini bertujuan untuk mengetahui tingkat pengetahuan khalayak sasaran terhadap materi yang akan diberikan sebelum dilakukan penyuluhan dan demonstrasi.

2. Evaluasi kedua, dilakukan setelah kegiatan penyuluhan, demonstrasi, dan praktik dengan memberikan kuisioner yang sama saat evaluasi pertama kemudian hasil evaluasi ini akan dinilai dan dilihat seberapa besar peningkatan pengetahuan dan keterampilan petani dalam perbanyakan tanaman durian dengan teknik okulasi.

3. Evaluasi ketiga, dilakukan dengan melihat \% keberhasilan okulasi tanaman yang berhasil.

\section{HASIL DAN PEMBAHASAN}

Kegiatan transfer teknologi okulasi durian di Kelompok Tani Harapan Baru I diawali dengan pemberian kuisioner kepada peserta penyuluhan. Pemberian kuisioner dilakukan sebelum kegiatan penyuluhan/diskusi dan demonstrasi dilakukan. Kuisioner yang diberikan pada evaluasi pertama ini berupa kuisioner yang berisi tentang ciri-ciri durian unggul dan teknik okulasi tanaman durian yang benar. Tahap ini bertujuan untuk mengetahui tingkat pengetahuan (kognitif) peserta penyuluhan mengenai ciri durian unggul dan teknik okulasi yang benar.

Berdasarkan hasil kuisioner diketahui bahwa tingkat pengetahuan awal petani mengenai ciri-ciri durian unggul sebesar $49.41 \%$. Sebagian petani sudah mengetahui ciri-ciri durian unggul antara lain berdaging tebal, dan memiliki rasa manis. Menurut Prastowo, Roshetko, Maurung, Nugraha, Tukan, dan Harum (2006) ciri-ciri durian unggul antara lain memiliki rasa daging buah manis berlemak, daging tebal, ukuran biji kecil, kadar air kecil (kering), tekstur halus sedikit berserat, ukuran buah besar, aroma kuat, jumlah juring 5-6 sempurna, dan kulit buah tipis serta mudah dibuka ketika sudah masak. Selain ciri-ciri tersebut, durian bisa dikatagorikan sebagai durian unggul karena memiliki ciri-ciri yang khas, misalnya durian tanpa duri (gundul) dan durian tanpa sekat yang berasal dari Lombok, Nusa Tenggara Barat.

Wilayah Batu Putuk memiliki beberapa durian yang berpotensi untuk dijadikan durian unggul nasional. Menurut Sesanti, Hidayat, dan Sudrajat (2013), di wilayah Batu Putuk terdapat durian tembaga (warna daging buah kuning orange), durian kucing tidur (bentuk buah unik, dan rasa gurih manis), durian Gading Gajah (ukuran besar), dan masih banyak lagi jenis durian lokal yang belum teridentifikasi. Banyaknya variasi jenis durian di Batu Putuk karena sebagian besar durian yang berada di wilayah tersebut ditanam dengan menggunakan biji dan merupakan durian 
warisan turun temurun. Belum ada usaha yang menyeluruh untuk melestarikan keanekaragaman durian di Batu Putuk.

Sampai saat ini baru satu kelompok tani yang berusaha melakukan perbanyakan tanaman durian untuk peremajaan dan mempertahankan plasma nutfah durian di Kelurahan Batu Putuk, yaitu Kelompok Tani Harapan Baru I. Namun demikian, tingkat keberhasilan okulasi durian di kelompok ini masih rendah (10.00\%), hal ini disebabkan tingkat pengetahuan anggota kelompok tani Harapan Baru I mengenai teknik okulasi durian hanya 18.82\% (Tabel 1.).

Tabel 1. Pengetahuan dan keterampilan awal peserta kegiatan Transfer Teknologi okulasi di Kelompok Tani Harapan Baru I, Kelurahan Batu Putuk, Kota Bandar Lampung

\begin{tabular}{clcc}
\hline No. & \multicolumn{1}{c}{ Pengetahuan dan Keterampilan } & $\begin{array}{c}\text { Tingkat pengetahuan dan } \\
\text { Keterampilan }(\%)\end{array}$ & Keterangan \\
\hline 1 & Pengetahuan mengenai Ciri-Ciri durian & $49.41 \%$ & Kuisioner \\
& Unggul & & Kuisioner \\
2 & Pengetahuan mengenai teknik okulasi durian & $18.82 \%$ & wawancara \\
3 & Keterampilan mengokulasi durian & $10.00 \%$ & \\
\hline
\end{tabular}

Setelah pemberian kuisioner pertama, dilakukan kegiatan penyuluhan dan demonstrasi. Materi yang disampaikan saat penyuluhan antara lain ciri-ciri durian unggul, dan perbanyakan tanaman duran secara okulasi. Sedangkan demonstrasi yang dilakukan adalah demonstrasi okulasi durian dengan dua tipe okulasi segi empat dan forkert.

Batang bawah yang digunakan saat demonstrasi adalah batang bawah durian yang berasal dari biji dan telah berumur 6 bulan. Batang bawah dipilih dengan kriteria batang sehat, subur dan tidak ada hama dan penyakit. Santoso, Haryanti, Pinem, dan Maryadi (2008) menjelaskan bahwa batang bawah yang dipilih diharapkan memiliki kriteria seperti perakaran yang kuat, tahan terhadap hama dan penyakit yang berada didalam tanah, mempunyai daya adaptasi yang kuat, tidak berpengaruh terhadap kuantitas dan kualitas buah, kompatibel dengan batang atas dan sehat.

Tanaman durian yang diperbanyak untuk tujuan komersil, diharuskan menggunakan entres (calon bagian atas tanaman yang akan diambil mata tunas nya) yang berasal dari pohon induk yang bersertifikat atau berasal dari varietas yang yang sudah dilepas oleh Menteri Pertanian. Namun dalam praktik okulasi yang dilakukan di Kelompok Tani Harapan Baru I batang atas yang digunakan adalah durian Belimbing (nama lokal). Durian belimbing dipilih karena memiliki rasa manis dan berwarna kuning, selain itu letak durian Belimbing dekat dengan lokasi praktik sehingga memudahkan saat pengambilan entres. Entres sebaiknya dipilih dari ranting-ranting tanaman dengan kriteria berwarna coklat kehijauan, terlihat segar dan diambil pada bagian tengah ranting. Menurut Sumarsono, Sjaefudin, Dimyati dan Abdurahman (2002) entres yang diambil $10-20 \mathrm{~cm}$ dari ujung ranting menghasilkan persen okulasi jadi yang lebih banyak (70\%) dibandingkan yang $10 \mathrm{~cm}$ dari ujung (60\%) dan diatas $20 \mathrm{~cm}$ dari ujung ranting (62\%).

Saat pelaksanaan penyuluhan dan demonstrasi peserta menunjukan tanggapan yang positif. Tanggapan positif dari peserta ditunjukan dengan jumlah peserta yang hadir melebihi jumlah undangan yang disebar dan banyaknya pertanyaan saat pelaksanaan diskusi. Tanggapan posistf juga terlihat saat dilaksanakan demonstrasi okulasi durian. Peserta memperhatikan demontrasi dengan serius. Selanjutnya saat praktik okulasi durian masing-masing peserta melakukan okulasi sesuai yang dicontohkan dan setiap peserta membuat 1 okulasi segi empat dan 1 okulasi forkert.

Tanggapan positif yang ditunjukan peserta penyuluhan merupakan tolak ukur tingginya keinginan peserta penyuluhan untuk memahami dan melakukan perbanyakan tanaman durian secara okulasi. 
Rizka Novi Sesanti, Hilman Hidayat, dan Nurman Abdul Hakim: Transfer Teknologi Okulasi Durian ...

Setelah pelaksanaan penyuluhan, demonstrasi dan praktik okulasi durian dilakukan evaluasi kedua. Evaluasi kedua dilakukan dengan memberikan kuisioner yang sama saat evaluasi pertama. Tujuan dari evaluasi kedua ini adalah untuk mengetahui tingkat keberhasilan kegiatan penyuluh dan demonstrasi. Indikator keberhasil penyuluhan dan demonstrasi ini ditandai dengan meningkatnya persentasi pengetahuan petani mengenai ciri-ciri durian unggul, dan teknik okulasi durian.

Berdasarkan kuisioner diketahui bahwa pengetahuan mengenai ciri-ciri durian unggul meningkat dari $49.41 \%$ menjadi $87.06 \%$. Selanjutnya, setelah dilakukan penyuluhan dan demonstrasi diketahui bahwa pengetahuan petani mengenai teknik okulasi durian meningkat dari $18.82 \%$ menjadi $87.06 \%$ (Tabel 2.).

Tabel 2 Pengetahuan dan keterampilan akhir peserta kegiatan Transfer Teknologi Perbanyakan Tanaman Durian di Kelompok Tani Harapan Baru I, Kelurahan Batu Putuk, Kota Bandar Lampung

\begin{tabular}{|c|c|c|c|}
\hline No. & Pengetahuan dan Keterampilan & $\begin{array}{c}\text { Tingkat pengetahuan dan } \\
\text { Keterampilan }(\%)\end{array}$ & Keterangan \\
\hline 1 & $\begin{array}{l}\text { Pengetahuan mengenai Ciri-Ciri durian } \\
\text { Unggul }\end{array}$ & $87.06 \%$ & Kuisioner \\
\hline 2 & Pengetahuan mengenai teknik okulasi durian & $87.06 \%$ & Kuisioner \\
\hline 3 & Keterampilan mengenai okulasi durian & $61.76 \%$ & Praktik \\
\hline
\end{tabular}

Satu bulan setelah kegiatan praktik okulasi durian dilakukan monitoring, hasil pengamatan dilapangan terlihat bahwa dari 34 okulasi yang dibuat oleh peserta sebanyak 19 okulasi yang jadi dengan ditandai mulai muncul bakal tunas pada mata tunas yang ditempel (pecah mata tunas). Dari 19 tersebut ternyata 8 buah okulasi yang jadi adalah okulasi segi empat, dan 13 okulasi forkert, dengan persentase keberhasilan okulasi total adalah 61,67\% (Tabel 3.).

Tabel 3. Keberhasilan okulasi durian

\begin{tabular}{|c|c|c|c|c|c|}
\hline \multirow{2}{*}{ No. } & \multirow{2}{*}{ Tipe Okulasi } & \multicolumn{2}{|c|}{ Jumlah okulasi } & \multicolumn{2}{|c|}{ Persentasi } \\
\hline & & Jadi & Tidak jadi & Jadi & Tidak jadi \\
\hline 1 & Segi empat & 8 & 9 & $47.05 \%$ & $52.95 \%$ \\
\hline 2 & Forkert & 13 & 4 & $64.70 \%$ & $35.30 \%$ \\
\hline & Total & 21 & 13 & $61.76 \%$ & $38.24 \%$ \\
\hline
\end{tabular}

Tingginya persentase jadi pada okulasi forkert disebabkan pada okulasi forket, sebagian kulit batang bawah tidak dibuang sehingga mata tunas dapat disisipkan pada kulit batang bawah (seperti kantung), hal ini membuat mata tunas menempel dengan sempurna pada batang bawah. Sedangkan pada okulasi segi empat, seluruh kulit batang bawah di buang sehingga mata tunas tidak disisipkan dan hanya ditempel, hal ini mungkin menyebabkan mata tunas tidak menempel sempurna, sehingga persentase okulasi jadi menjadi rendah. Okulasi forkert dan okulasi segi empar disajikan pada Gambar 1. 


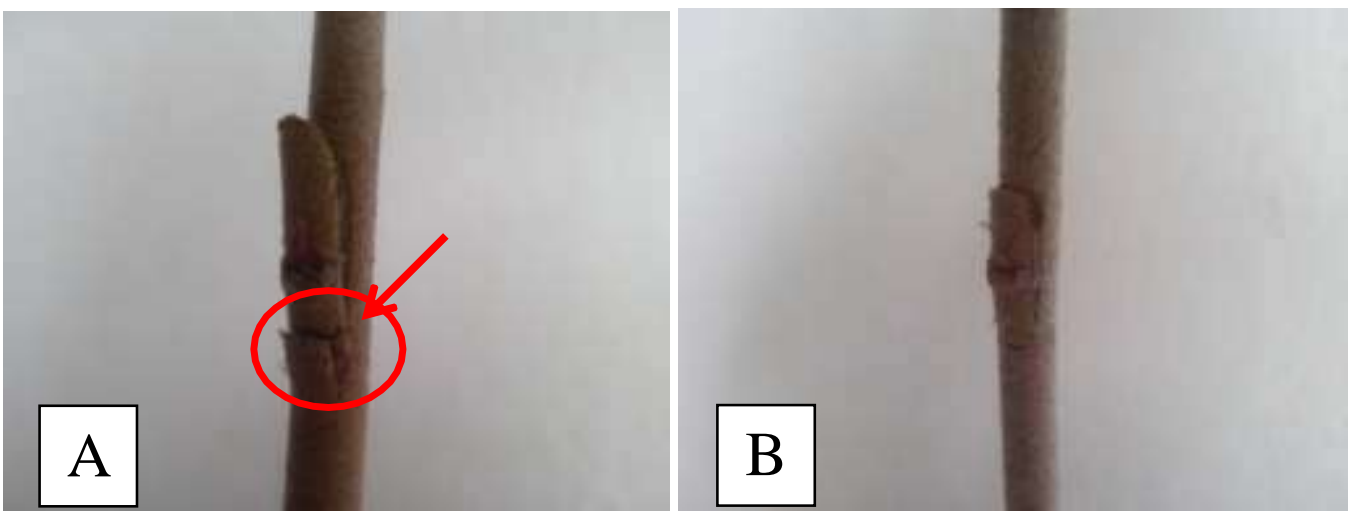

Gambar 1. Okulasi forkert (A), dan okulasi segi empat (B)

\section{KESIMPULAN}

Kesimpulan dari kegiatan transfer teknologi okulasi durian di Kelompok TaniHarapan Baru I Kelurahan Batu Putuk adalah sebagai berikut:

1. Pengetahuan anggota Kelompok Tani Harapan Baru I mengenai ciri-ciri durian unggul mencapai $87.06 \%$.

2. Pengetahuan anggota Kelompok Tani Harapan Baru I mengenai perbanyakan tanaman durian dengan teknik okulasi mencapai 87.06\%.

3. Keterampilan petani dalam perbanyakan tanaman durian dengan teknik okulasi meningkat dari $10 \%$ menjadi $60 \%$.

\section{DAFTAR PUSTAKA}

BPS.2012. Kota Bandar Lampung dalam angka. BPS Kota Bandar Lampung. Bandar Lampung. ISSN 0217-4102.

Kelompok Tani Harapan Baru I. 2013. Profil pelaku usaha/Kelompok Usaha Komoditas Perkebunan. Dinas Pertanian Kota Bandar Lampung.

Prastowo NH., Roshetko JM., Maurung GES.,Nugraha E., Tukan JM., Harum F. 2006. Teknik Pembibitan dan Perbanyakan Vegetatif Tanaman Buah. World Agroforestry Centre (ICRAF) and Winrock International.

Santoso AP., Haryanti SE., Pinem RTR., dan Maryadi.2008. Sertifikasi Benih Durian. Direktorat Perbenihan dan Sarana Produksi Direktorat Jenderal Hortikultura. ISBN 978-979-16946-98

Sesanti, Hidayat, dan Sudrajat. 2013. Identifikasi dan Penilaian Karakter Morfologi Tujuh Durian Lokal Yang Berasal dari Kelurahan Batu Putuk Kota Bandar Lampung. Laporan Penelitian. Politeknik Negeri Lampung. Lampung.

Sumarsono L., Sjaefuddin A., Dimyati D., Abdurahman. 2002. Teknik Okulasi Bibit Durian pada Stadia Entres dan Model Mata Tempel yang Berbeda. Buletin Teknik Pertanian Vol. 7 No. 1. 